\title{
Effect of radiation dose to the periventricular zone and subventricular zone on survival in anaplastic gliomas
}

\author{
Deepthi Valiyaveettil ${ }^{1}$, Monica Malik ${ }^{1}$ and Deepa M Joseph $^{2}$ \\ ${ }^{1}$ Department of Radiation Oncology, Nizam's Institute of Medical Sciences, Punjagutta, Hyderabad 500082, India \\ ${ }^{2}$ Department of Radiation Oncology, All India Institute of Medical Sciences, Rishikesh 249203, India
}

\section{Abstract}

Purpose: Evidence suggests a correlation of subventricular zone (SVZ) irradiation on survival. Most of the data have been analysed in glioblastoma patients. The aim of this study is to analyse the dose to the subventricular and periventricular zone and its outcomes in anaplastic gliomas.

Materials and methods: A retrospective analysis of patients with anaplastic gliomas were admitted for post-chemoradiation from January 2010 to June 2016 was done from treatment records. SVZ was contoured as $5 \mathrm{~mm}$ expansion along the lateral margin of the lateral ventricles, and PVZ was contoured as $5 \mathrm{~mm}$ lateral expansion adjacent to ventricles. Dosimetric data were collected from the treatment planning system.

Results: Ninety-five patients were included in the analysis. The median age was 35 years. Two- and five-year overall survival (OS) for the entire group was $84 \%$ and $54.2 \%$, respectively. Two- and five-year progression-free survival (PFS) was $79.8 \%$ and $50.6 \%$, respectively. Patients receiving $<54$ Gy to the i/I SVZ showed a significantly better PFS and OS. 5 -Year OS was $72.6 \%$ in this group compared to $37 \%$ for the group receiving $\geq 54 \mathrm{~Gy}(p=0.01)$. Five-year PFS was $69.9 \%$ in this group compared to $31.9 \%$ for the group receiving $\geq 54 \mathrm{~Gy}(p=0.02)$. However, this was not significant in multivariate analysis.

Conclusion: Increased dose to the ipsilateral SVZ does not correlate with improved survival in anaplastic gliomas. There is conflicting evidence regarding the benefit of irradiating the stem cell zones. Future studies should focus on optimizing doses to these areas to reduce detriment in neurocognition.

Keywords: subventricular zone, anaplastic gliomas, neurocognition, periventricular zone

\section{Background}

High-grade gliomas (HGG) are the most common brain tumours. They are usually aggressive and difficult to control despite advances in multimodality management. Radiotherapy plays a critical role in the management of these tumours.

Correspondence to: Monica Malik

Email: dr_monica11@yahoo.com

ecancer 2019, 13:956

https://doi.org/10.3332/ecancer.2019.956

Published: $31 / 07 / 2019$

Received: 21/03/2019

Publication costs for this article were supported by ecancer (UK Charity number 1176307).

Copyright: $($ ) the authors; licensee ecancermedicalscience. This is an Open Access article distributed under the terms of the Creative Commons Attribution License (http:// creativecommons.org/licenses/by/3.0), which permits unrestricted use, distribution, and reproduction in any medium, provided the original work is properly cited. 
The origin of HGGs is still not clearly understood. Initially, they were hypothesized to originate from neoplastic transformation of glial cells $[1,2]$. Later, the concept of cancer stem cells emerged [3, 4]. Recent research in glioblastoma suggests that the heterogeneity seen may be related to the cells of origin, which have stem-cell-like characteristics $[3,5,6]$.

In an adult mammalian brain, a 3-5-mm-thick lateral periventricular region of the lateral ventricles [subventricular zone (SVZ)] and a subsection of the hippocampal formation (subgranular layer) are considered as germinal areas. They harbour normal neural stem cells that maintain the ability to generate neurons and glia throughout adulthood [7-9]. Periventricular zone (PVZ) is the region surrounding the ventricles. The SVZ has been described as the 'largest niche of neurogenesis in the adult mammalian brain' [8, 10, 11]. The neural stem cells (NSCs) in these areas are being studied extensively for therapeutic applications because of their ability to proliferate. These newly generated cells are able to migrate and differentiate into any of the main cell types of the central nervous system (CNS) $[8,9,12,13]$.

These cells also play an important role in the repair of injury within the CNS [14, 15], including recovery from radiation-induced damage [16, 17]. Stem cells within the SVZ and subgranular zone (SGZ) are thought to play functional roles in memory and neurocognition [7, 14, 18]. Damage to the NSCs during radiation therapy can have detrimental effects $[19,20]$.

A few retrospective studies demonstrated that patient survival and recurrence patterns in glioblastoma may be related to neuronal stem cells, located in the SVZ [5, 21]. Several groups have correlated higher radiation doses to the SVZ and SGZ areas with improved survival outcomes in glioblastoma patients [22-25]. Given this potential relationship between radiation doses to regions containing neural stem cells and survival outcomes in glioblastoma, we aimed to explore this further in anaplastic gliomas.

To test our hypothesis, we performed a retrospective analysis of radiation treatment plans of anaplastic glioma patients admitted for adjuvant radiation to study the effect of the radiation dose inadvertently delivered to the SVZ on the survival outcomes.

\section{Materials and methods}

Patients with histopathologically diagnosed anaplastic gliomas consecutively treated in our institute from January 2010 to June 2016 were included in this retrospective analysis. Patients who failed to complete the radiation prescription were excluded from the study. Patient data, including demographics, imaging data, treatment and clinical outcomes were collected from treatment and follow-up records. Patient demographics, tumour characteristics and treatment details were correlated with survival outcomes.

\section{Treatment}

All patients had undergone maximal safe resection. The extent of resection was identified as gross total or subtotal resection or biopsy by operative and clinical notes and when available by post-operative CT or MRI imaging. The planning target volume (PTV) for each patient was designated by the treating physician at the time of initial treatment planning.

The CT simulation scan was obtained with 3-mm slice thickness and was fused to pre- and postoperative MRI data. Gross tumour volume (GTV) included the resection cavity and any gross residual tumour observed on postoperative MRI. The clinical target volume (CTV) was defined by GTV and hyperintense area on T2 FLAIR MRI plus a 1.5-2-cm margin accounting for a potential microscopic extension. The PTV1 was CTV plus a 5-mm margin in all directions to account for daily setup uncertainty. A subsequent boost was given to PTV2, which was defined as GTV plus a 1-cm margin. Radiotherapy was delivered by three-dimensional conformal radiotherapy or intensity modulated radiotherapy (IMRT), with a standard dose of $60 \mathrm{~Gy}$ in 30 daily fractions, 5 days per week. Temozolomide was given as concurrent (75 mg/ $\mathrm{m}^{2} /$ day) and adjuvant chemotherapy (150-200 $\mathrm{mg} / \mathrm{m} 2$ for 5 days every 28 days for $6-12$ cycles).

\section{SVZ}

Tumours were divided into groups (contacting and non-contacting) based on their spatial relationship to the SVZ. SVZs were contoured according to published guidelines [26] onaxial planning CT scans as 5-mm expansion along the lateral margin of the lateral ventricles. PVZ 
was contoured as 5-mm lateral expansion adjacent to ventricles. Tumour epicentre was used to assign laterality of the SVZ. Ipsilateral (i/I), contralateral (c/I) and bilateral (b/I) SVZ and PVZs were contoured on the co-registered MRI and CT images. Tumours were termed as SVZ contacting tumours if there was a distance of $0 \mathrm{~mm}$ between the contrast-enhancing tumour edge and the SVZ.

\section{Dosimetry}

Treatment planning system was Eclipse version 8.6 (Varian Medical Systems). Dose-volume histograms were generated on the original plans and dose-volume parameters for each SVZ and PVZ volume were extracted. Volume and dose to the i/l, c/l, and b/I SVZ and PVZ were documented as a continuous variable.

\section{Statistics}

Survival analysis: The study used progression-free survival (PFS) and overall survival (OS) as the main outcome determinants. PFS was calculated from the date of the initial surgical resection to disease progression, or to the last recorded date of follow-up without progression. OS was defined as the duration from the date of the primary surgery to the date of death or last contact. Survival interval was represented in months.

Overall survival was estimated as median and with 95\% confidence interval (Cls). Kaplan-Meier (KM) survival curves were used to visualise the impact on survival for a significant prognostic factor. Log-rank test was used to estimate univariable significance for KM curves. Multivariate analysis was assessed using the Cox proportional hazards model, including significant covariates in univariate analysis. All reported $p$-values were two-sided. For all statistical tests, differences were considered significant at the $5 \%$ level. Statistical analysis was done using SPSS v20 software (IBM Corp. in Armonk, NY).

\section{Results}

A total of 120 consecutive patient records were retrieved for this study. Ninety-five patients who had completed the course of radiation prescribed and had follow-up details were included in the study. The median age was 35 years, range 6-68 years. All patient characteristics are tabulated in Table 1.

The most common symptom at the time of presentation was headache (57.8\%), followed by seizures, nausea and vomiting and hemiparesis. 55 patients (58\%) had tumours confined to single lobe, frontal lobe being the most common. 72 patients (75.7\%) had tumours contacting the subventricular region radiologically.

All the patients underwent maximal safe resection. Gross total excision was done in $27.3 \% .51 .5 \%$ were anaplastic astrocytomas and $32.6 \%$ had anaplastic oligodendrogliomas as histopathology. Immunohistochemistry (IHC) testing was available in our institute from 2014 . IHC data including IDH1 mutational analysis, ATRX, ki-67 and 1p19q co-deletion testing were available in 37.8\% of cases.

The majority of patients ( $84.2 \%$ ) had performance status (PS) of $\leq 2$ by ECOG scoring system at the time of presentation during RT. 84 ( $88.4 \%$ ) received concurrent chemotherapy with temozolomide and 72 (75.7\%) patients received adjuvant chemotherapy. Median number of adjuvant chemotherapy cycles was six.

Median doses received by i/l, c/I and b/I SVZ were 54 Gy, 37 Gy and 45 Gy, respectively. The median dose received by i/l, c/l and b/I PVZ was 53 Gy, 37 Gy and 45 Gy, respectively. All dosimetric data are tabulated in Table 2.

\section{Survival analysis}

To reduce the heterogeneity of the population, survival analysis excluded children and tumours involving cerebellum. 85 patients were included. Median follow up was 39 months (Range: 5-92 months). 
Table 1. Patient, disease and treatment characteristics.

\begin{tabular}{|c|c|}
\hline Patient variables $(N=65)$ & No. of patients (\%) \\
\hline Mean and median age in years (range) & 35 and $35.29(6-68)$ \\
\hline $\begin{array}{l}\text { Sex } \\
\text { Male } \\
\text { Female }\end{array}$ & $\begin{array}{l}62(65.3 \%) \\
33(34.7 \%)\end{array}$ \\
\hline $\begin{array}{l}\text { ECOG performance status } \\
\leq 2 \\
>2\end{array}$ & $\begin{array}{l}80 \text { (84.2\%) } \\
15 \text { (15.7\%) }\end{array}$ \\
\hline $\begin{array}{l}\text { Chief presenting complaints } \\
\text { Headache } \\
\text { Seizures } \\
\text { Nausea \& vomiting } \\
\text { Weakness and paraesthesias }\end{array}$ & $\begin{array}{l}55(57.8 \%) \\
44(49.3 \%) \\
20(21.0 \%) \\
18(18.9 \%)\end{array}$ \\
\hline Mean duration of symptoms in months & 8.2 months \\
\hline $\begin{array}{l}\text { Location of tumour } \\
\text { Confined to single lobe } \\
\text { Two lobes } \\
\text { Three lobes } \\
\text { Cerebellum } \\
\text { Brainstem }\end{array}$ & $\begin{array}{c}55 \text { (57.98\%) 34-frontal (61.8\%) } \\
28(29.4 \%) \\
1(1.05 \%) \\
5(5.2 \%) \\
3(3.1 \%)\end{array}$ \\
\hline $\begin{array}{l}\text { Tumour contacting SVZ } \\
\text { Yes } \\
\text { No }\end{array}$ & $\begin{array}{c}N(\%) \\
72(75.7 \%) \\
23(24.2 \%)\end{array}$ \\
\hline $\begin{array}{l}\text { Extent of resection } \\
\text { Gross total resection } \\
\text { Subtotal resection } \\
\text { Biopsy/decompression }\end{array}$ & $\begin{array}{l}26(27.3 \%) \\
59(62.1 \%) \\
10(10.5 \%)\end{array}$ \\
\hline $\begin{array}{l}\text { Post op histopathology } \\
\text { Anaplastic astrocytoma (AA) } \\
\text { Anaplastic oligodendroglioma } \\
\text { Anaplastic oligoastrocytoma } \\
\text { Anaplastic pilocytic astrocytoma } \\
\text { AA with gemistocytic variant } \\
\text { Diffuse fibrillary astrocytoma with anaplasia }\end{array}$ & $\begin{array}{c}49(51.5 \%) \\
31(32.6 \%) \\
8(8.4 \%) \\
5(5.2 \%) \\
1(1.05 \%) \\
1(1.05 \%)\end{array}$ \\
\hline $\begin{array}{l}\text { Immunohistochemistry } \\
\text { Yes } \\
\text { No }\end{array}$ & $\begin{array}{l}36(37.8 \%) \\
59(62.1 \%)\end{array}$ \\
\hline $\begin{array}{l}\text { Radiotherapy technique } \\
\text { 3DCRT } \\
\text { IMRT }\end{array}$ & $\begin{array}{l}17 \text { (17.8\%) } \\
78(82.1 \%)\end{array}$ \\
\hline $\begin{array}{l}\text { Concurrent chemotherapy with TMZ } \\
\text { Yes } \\
\text { No }\end{array}$ & $\begin{array}{l}84 \text { (88.4\%) } \\
11(11.5 \%)\end{array}$ \\
\hline $\begin{array}{l}\text { Adjuvant chemotherapy with TMZ } \\
\text { Yes } \\
\text { No } \\
\text { Mean number of cycles } \\
>6 \text { cycles }\end{array}$ & $\begin{array}{c}72(75.7 \%) \\
23(24.2 \%) \\
6 \\
16(22.2 \%)\end{array}$ \\
\hline
\end{tabular}

$N=$ Total number of patients in the study, ECOG = Eastern Cooperative Oncology Group, SVZ = Subventricular zone, 3DCRT $=$ Three-dimensional conformal radiotherapy, IMRT = Intensity-modulated radiotherapy, $\mathrm{TMZ}=$ Temozolomide 
Table 2. Dosimetric data.

\begin{tabular}{|l|l|}
\hline \multicolumn{1}{|c|}{ Dosimetric variables } & \multicolumn{1}{c|}{ Dose in gray } \\
\hline Volumes & Mean \pm SD \\
Ipsilateral SVZ & $6.41 \pm 5.6$ \\
Contralateral SVZ & $7.40 \pm 3.56$ \\
Bilateral SVZ & $12.86 \pm 5.05$ \\
Ipsilateral PVZ & $13.80 \pm 6.22$ \\
Contralateral PVZ & $17.52 \pm 6.39$ \\
Bilateral PVZ & $30.99 \pm 11.62$ \\
\hline Doses & Mean \pm SD, Median \\
Ipsilateral SVZ & $51.73 \pm 8.91,54$ \\
Contralateral SVZ & $36.79 \pm 8.75,37$ \\
Bilateral SVZ & $42.82 \pm 8.73,45$ \\
Ipsilateral PVZ & $50.02 \pm 10.24,53$ \\
Contralateral PVZ & $36.33 \pm 8.70,37$ \\
Bilateral PVZ & $42.60 \pm 8.54,45$ \\
\hline
\end{tabular}

SVZ = subventricular zone, $\mathrm{PVZ}=$ periventricular zone, $\mathrm{SD}=$ Standard Deviation

2-year and 5-year OS for the entire group was $87.5 \%$ and 55.7\%, respectively. 2-year and 5-year PFS for the entire group was $83.3 \%$ and $52.3 \%$, respectively. Age and gender did not significantly impact OS or PFS.

Patients receiving $\leq 54 \mathrm{~Gy}$ to the $\mathrm{i} / \mathrm{I}$ subventricular zone showed a significantly better PFS. 2- and 5-year PFS was $86.2 \%$ and $75.5 \%$ in this group compared to $81.1 \%$ and $33.3 \%$ for the group receiving $>54 \mathrm{~Gy}(p=0.01)$, respectively. 2 - and 5 -year PFS was $87.5 \%$ and $79.3 \%$ in the group receiving $<52 \mathrm{~Gy}$ to the $\mathrm{i} / \mathrm{I}$ periventricular zone compared to $69.3 \%$ and $41.2 \%$ for group receiving $\geq 52 \mathrm{~Gy}(p=0.01)$, respectively. However, the multivariate analysis did not show significant results. Other dosimetric correlations are documented in Table 3 and Kaplan-Meier survival estimates are shown in Figure 1.

During follow-up, 22 (23.1\%) patients developed progression, of which 18 patients received salvage treatment with surgery in 15 patients and re-irradiation in six patients. Three patients received concurrent and adjuvant temozolomide during re-irradiation.

\section{Discussion}

According to the cancer stem cells (CSC) hypothesis, all CSCs need to be eliminated in order to cure cancer [27]. The SVZ and PVZ are hypothesized as germinal centres which house these cells. Tumour contact with these regions has shown to be an independent adverse prognostic factor in many studies [28].

In a retrospective analysis, 53 patients with newly diagnosed glioblastoma were classified based on their spatial relationship to the SVZ. Results showed that patients whose tumours made contact with the SVZ had a significantly higher incidence of multifocal disease at diagnosis and also had decreased OS and PFS [5]. A similar analysis of 91 glioblastoma patients showed significantly reduced PFS in patients whose tumour had contact with both the SVZ and the cortex [21]. In our study, tumours contacting the SVZ preoperatively had reduced survival compared to the non-contacting group but this result was not statistically significant.

Preclinical studies and retrospective clinical evidence [22-25, 29-31] have established a correlation between radiation dose to the SVZ and survival, suggesting a favourable impact of irradiation to the SVZ. Most of these studies included only glioblastomas.

The first retrospective study [25] to analyse the effect of a high dose of radiation to neural stem cell niches included 55 adult patients with Grade 3 or Grade 4 gliomas. This study showed significant improvement in PFS in patients whose b/I SVZ received a dose of 43 Gyor more (15.0 vs 7.2 months; $p=0.028$ ). There was no improvement in overall survival. This study included 17 (30\%) patients with anaplastic gliomas. 
Table 3. Survival analysis and dosimetric correlations.

\begin{tabular}{|c|c|c|c|c|c|c|}
\hline Variable $(n)$ & 2 year OS in \% & 5 year OS in \% & $p$ value & 2 year PFS in \% & 5 year PFS in \% & $p$ value \\
\hline $\begin{array}{l}\text { Age } \\
\leq 35 \text { years }(n=46) \\
>35 \text { years }(n=39)\end{array}$ & $\begin{array}{l}89.1 \\
70.2\end{array}$ & $\begin{array}{l}61.8 \\
49.4\end{array}$ & 0.54 & $\begin{array}{l}84.8 \\
81.4\end{array}$ & $\begin{array}{l}48.7 \\
55.3\end{array}$ & 0.47 \\
\hline $\begin{array}{l}\text { Sex } \\
\text { Male }(n=56) \\
\text { Female }(n=29)\end{array}$ & $\begin{array}{l}78.3 \\
93.0 \\
\end{array}$ & $\begin{array}{l}54.2 \\
59.5 \\
\end{array}$ & 0.55 & $\begin{array}{l}81.8 \\
86.2 \\
\end{array}$ & $\begin{array}{l}49.1 \\
58.2\end{array}$ & 0.31 \\
\hline $\begin{array}{l}\text { SVZ contacting } \\
\begin{array}{l}\text { Yes }(n=69) \\
\text { No }(n=16)\end{array}\end{array}$ & $\begin{array}{c}85 \\
100\end{array}$ & $\begin{array}{l}53.8 \\
63.5\end{array}$ & 0.27 & $\begin{array}{l}80.9 \\
93.8\end{array}$ & $\begin{array}{l}49.9 \\
62.5\end{array}$ & 0.30 \\
\hline $\begin{array}{l}\text { SVZ i/l } \\
\quad<54 \text { Gy }(n=37) \\
\geq 54 \text { Gy }(n=48)\end{array}$ & $\begin{array}{l}85.8 \\
89.4\end{array}$ & $\begin{array}{l}74.8 \\
40.2 \\
\end{array}$ & 0.01 & $\begin{array}{l}86.2 \\
81.1\end{array}$ & $\begin{array}{l}75.5 \\
33.3 \\
\end{array}$ & 0.01 \\
\hline $\begin{array}{l}\text { SVZ c/I } \\
\quad<37 \text { Gy }(n=41) \\
\geq 37 \text { Gy }(n=44)\end{array}$ & $\begin{array}{l}85.1 \\
93.1 \\
\end{array}$ & $\begin{array}{l}58.1 \\
53.5\end{array}$ & 0.76 & $\begin{array}{l}82.6 \\
84.0\end{array}$ & $\begin{array}{l}54.6 \\
50.3 \\
\end{array}$ & 0.75 \\
\hline $\begin{array}{l}\text { SVZ b/l } \\
\quad<44 \text { Gy }(n=42) \\
\geq 44 \text { Gy }(n=43)\end{array}$ & $\begin{array}{l}77.2 \\
97.7\end{array}$ & $\begin{array}{l}59.2 \\
51.6\end{array}$ & 0.98 & $\begin{array}{l}75.1 \\
90.9\end{array}$ & $\begin{array}{l}60.5 \\
45.5\end{array}$ & 0.94 \\
\hline $\begin{array}{l}\text { PVZ i/l } \\
\quad<52 \text { Gy }(n=41) \\
\geq 52 \mathrm{~Gy}(n=44)\end{array}$ & $\begin{array}{l}87.2 \\
88.5\end{array}$ & $\begin{array}{l}70.2 \\
42.3\end{array}$ & 0.06 & $\begin{array}{l}87.5 \\
79.3\end{array}$ & $\begin{array}{l}73.3 \\
35.4\end{array}$ & 0.03 \\
\hline $\begin{array}{l}\text { PVZ c/l } \\
\quad<37 \text { Gy }(n=42) \\
\geq 37 \mathrm{~Gy}(n=43)\end{array}$ & $\begin{array}{l}80.0 \\
95.3\end{array}$ & $\begin{array}{l}60.6 \\
52.0\end{array}$ & 0.69 & $\begin{array}{l}80.6 \\
86.0\end{array}$ & $\begin{array}{l}61.2 \\
45.2\end{array}$ & 0.46 \\
\hline $\begin{array}{l}\text { PVZ b/I } \\
\quad<44 \text { Gy }(n=42) \\
\geq 44 \text { Gy }(n=43)\end{array}$ & $\begin{array}{l}76.2 \\
97.8\end{array}$ & $\begin{array}{l}65.5 \\
47.8\end{array}$ & 0.64 & $\begin{array}{l}76.5 \\
89.1\end{array}$ & $\begin{array}{l}69.3 \\
41.2\end{array}$ & 0.19 \\
\hline
\end{tabular}

$\mathrm{SVZ}=$ subventricular zone, $\mathrm{PVZ}=$ periventricular zone, $\mathrm{i} / \mathrm{I}=$ ipsilateral, $\mathrm{c} / \mathrm{I}=$ contralateral, $\mathrm{b} / \mathrm{I}=$ bilateral

A retrospective pooled analysis of glioblastoma patients by Lee et al [23] showed that patients receiving more than 59.4 Gy to the i/l SVZ reported improvements in both PFS and OS. Another retrospective analysis conducted in India by Gupta et al [24] observed improvement in overall survival in glioblastoma patients treated with higher mean dose to the i/l SVZ.

A recent retrospective study [31] was conducted to identify SVZ related prognostic factors for survival and recurrence patterns. This study included 43 patients with primary glioblastoma. Results showed contact to SVZ, as well as reduced b/I SVZ radiation dose coverage (V20Gy <84\%), might be independent poor prognostic factors for time to progression (7 months versus 5.2 months, $p=0.017$ ) on multivariate analysis.

These studies suggest that higher doses targeted to the SVZ improve the progression-free survival [25] (PFS) of patients compared to dose targeted to the tumour alone. Additionally, increasing the mean radiation dose to the i/I SVZ was associated with significantly improved OS $[22,24]$. These results are important and suggest that higher radiation dose to the SVZ may be beneficial in terms of survival outcomes.

In tune with these reports, a prospective study of hypofractionated radiation therapy found improved survival in long-term survivors with necrosis in the SVZ [32]. A recent single arm clinical trial investigating planned neural stem cell niche irradiation in glioblastoma [33] showed mean dose of $58 \mathrm{~Gy}$ or greater to the i/l SVZ correlated positively with improved overall survival (16 months versus 14 months, $p=0.03$ ). 

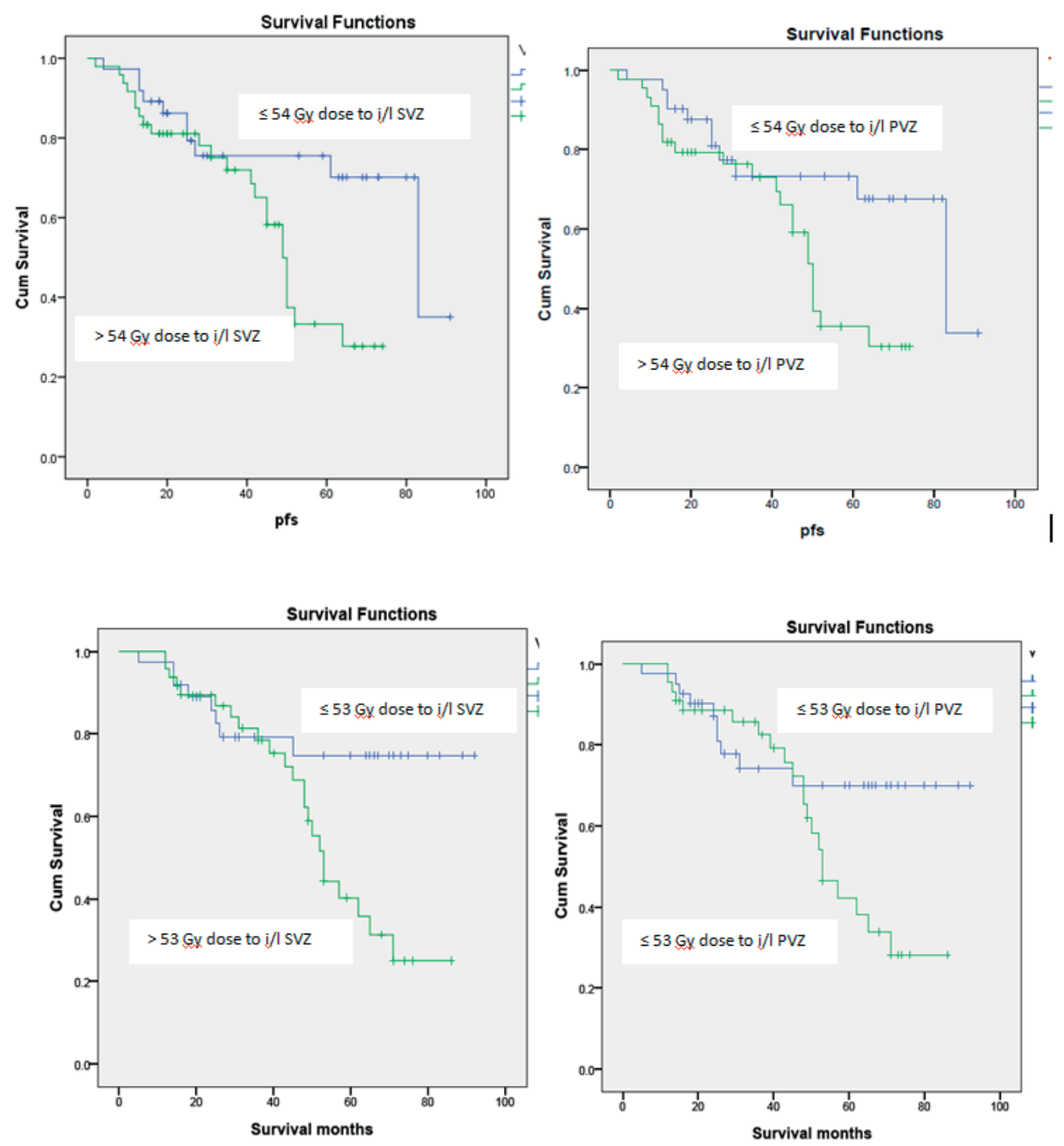

Figure 1. Kaplan-Meier estimates for progression free survival and overall survival.

All these studies point towards increasing the dose of radiation for improved survival. On the contrary, there have been studies which showed detrimental results with increased SVZ doses. A study by Elicin et al [30] found a worse PFS among patients with high i/l SVZ dose (>62.25 Gy) in both subgroups of good performance status and SVZ without tumoural contact. A worse PFS was also found among patients with higher doses to $\mathrm{c} / \mathrm{I} \mathrm{SVZ}>59.2 \mathrm{~Gy}$ (7.1 versus 10.4 months), but it was not confirmed in multivariate analysis.

A recent prospective study [34] conducted showed patients who received <59 Gy to the i/I SVZ had significantly better outcomes than patients who received greater than $59 \mathrm{~Gy}$ to the $\mathrm{i} / \mathrm{I}$ SVZ both in terms of median PFS (20.5 versus 9.7 months, $p=0.016)$ and OS (20.6 versus 13.3 months, $p=0.026$ ). Similar to these results, our study has also showed that patients receiving $<54 \mathrm{~Gy}$ to the i/I SVZ had significantly better PFS and OS at 5 years, although our study included only patients with anaplastic glioma histology. 
Although these studies show that the plasticity of the SVZ has quantifiable benefits for the adult brain, it comes with a potential limitation. Studies in patients with gliomas have suggested a potential risk of developing neurocognitive sequelae when the NSCs are irradiated during radiotherapy, most notably in children [35-40]. Although an association between the RT dose to the hippocampus and neurocognitive function has been studied, the relationship between RT dose to the SVZ and neurocognitive function is controversial [41-43].

The available literature on the effects of irradiation of SVZ in anaplastic gliomas is sparse. The prognosis of anaplastic gliomas is better compared to glioblastoma. Many of these patients have reported longer survival. Therefore, the implications of neurocognitive effects should be kept in mind. Irradiation of SVZ in these patients remains an interesting academic question which is likely to have important implications for radiation treatment planning strategies in the future. The present evidence of subventricular zone dose in glioblastoma shows contradictory results. Our study could not demonstrate any benefit from higher doses to SVZ or PVZ in anaplastic gliomas.

Limitations: Our study has inherent biases of a retrospective study. Immuno-histochemistry was not available in all patients. Neuro-cognition pre and post RT was not tested. The patterns of failures were not analysed in relation to any of the SVZ dose-volume parameters.

\section{Conclusions}

Increased dose to the ipsilateral subventricular zone does not correlate with improved survival in anaplastic gliomas. There is conflicting evidence in the literature regarding the benefit of irradiating the stem cell zones in gliomas. This may suggest that the relationship between these zones and survival is not clearly understood. Future studies should focus on optimising doses to these areas to reduce detriment in neurocognition.

\section{Conflicts of interest}

All authors declare no conflict of interest

\section{Authors' contributions}

All authors contributed substantially to this work.

\section{Funding/financial support received}

The authors received no funding for this article.

\section{References}

1. Sanai N, Alvarez-Buylla A, and Berger MS (2005) Neural stem cells and the origin of gliomas N Engl J Med 353(8) 811-822 https://doi. org/10.1056/NEJMra043666 PMID: 16120861

2. Holland EC (2001) Progenitor cells and glioma formation Curr Opin Neurol 14(6) 683-688 https://doi.org/10.1097/00019052200112000-00002 PMID: 11723374

3. Galli R, Binda E, and Orfanelli U, et al (2004) Isolation and characterization of tumorigenic, stem-like neural precursors from human glioblastoma Cancer Res 64(19) 7011-7021 https://doi.org/10.1158/0008-5472.CAN-04-1364 PMID: 15466194

4. Singh SK, Hawkins C, and Clarke ID, et al (2004) Identification of human brain tumour initiating cells Nature 432(7015) 396-401 https://doi.org/10.1038/nature03128 PMID: 15549107 
5. Lim DA, Cha S, and Mayo MC, et al (2007) Relationship of glioblastoma multiforme to neural stem cell regions predicts invasive and multifocal tumor phenotype Neuro-oncology 9(4) 424-429 https://doi.org/10.1215/15228517-2007-023 PMID: 17622647 PMCID: 1994099

6. Bao S, Wu Q, and McLendon RE, et al (2006) Glioma stem cells promote radioresistance by preferential activation of the DNA damage response Nature 444(7120) 756-760 https://doi.org/10.1038/nature05236 PMID: 17051156

7. Eriksson PS, Perfilieva E, and Björk-Eriksson T, et al (1998) Neurogenesis in the adult human hippocampus Nat Med 41313 https://doi. org/10.1038/3305 PMID: 9809557

8. Alvarez-Buylla A and Garcia-Verdugo JM (2002) Neurogenesis in adult subventricular zone J Neurosci 22(3) 629-634 https://doi.org/10.1523/ JNEUROSCI.22-03-00629.2002 PMID: 11826091

9. Ming GL and Song H (2005) Adult neurogenesis in the mammalian central nervous system Ann Rev Neurosci 28 223-250 https://doi. org/10.1146/annurev.neuro.28.051804.101459 PMID: 16022595

10. Quinones-Hinojosa A and Chaichana K (2007) The human subventricular zone: a source of new cells and a potential source of brain tumors Exp Neurol 205(2) 313-324 https://doi.org/10.1016/j.expneurol.2007.03.016 PMID: 17459377

11. Doetsch F, Caille I, and Lim DA, et al (1999) Subventricular zone astrocytes are neural stem cells in the adult mammalian brain Cell 97(6) 703-716 https://doi.org/10.1016/S0092-8674(00)80783-7 PMID: 10380923

12. Abrous DN, Koehl M, and Le Moal M (2005) Adult neurogenesis: from precursors to network and physiology Physiol Rev 85(2) 523-569 https://doi.org/10.1152/physrev.00055.2003 PMID: 15788705

13. Menn B, Garcia-Verdugo JM, and Yaschine C, et al (2006) Origin of oligodendrocytes in the subventricular zone of the adult brain J Neurosci 26(30) 7907-7918 https://doi.org/10.1523/JNEUROSCI.1299-06.2006 PMID: 16870736

14. Arvidsson A, Collin T, and Kirik D, et al (2002) Neuronal replacement from endogenous precursors in the adult brain after stroke Nat Med 8(9) 963-970 https://doi.org/10.1038/nm747 PMID: 12161747

15. Goings GE, Sahni V, and Szele FG (2004) Migration patterns of subventricular zone cells in adult mice change after cerebral cortex injury Brain Res 996(2) 213-226 https://doi.org/10.1016/j.brainres.2003.10.034

16. Francois S, Bensidhoum M, and Mouiseddine M, et al (2006) Local irradiation not only induces homing of human mesenchymal stem cells at exposed sites but promotes their widespread engraftment to multiple organs: a study of their quantitative distribution after irradiation damage Stem Cells 24(4) 1020-1029 https://doi.org/10.1634/stemcells.2005-0260

17. Mouiseddine M, Francois S, and Semont A, et al (2007) Human mesenchymal stem cells home specifically to radiation-injured tissues in a non-obese diabetes/severe combined immunodeficiency mouse model Br J Radiol 80 Spec No 1 S49-S55 https://doi.org/10.1259/ bjr/25927054 PMID: 17704326

18. Quinones-Hinojosa A, Sanai N, and Soriano-Navarro M, et al (2006) Cellular composition and cytoarchitecture of the adult human subventricular zone: a niche of neural stem cells J Comp Neurol 494(3) 415-434 https://doi.org/10.1002/cne.20798

19. Marazziti D, Baroni S, and Catena-Dell'Osso M, et al (2012) Cognitive, psychological and psychiatric effects of ionizing radiation exposure Curr Med Chem 19(12) 1864-1869 https://doi.org/10.2174/092986712800099776 PMID: 22376039

20. Achanta P, Fuss M, and Martinez JL, Jr (2009) lonizing radiation impairs the formation of trace fear memories and reduces hippocampal neurogenesis Behav Neurosci 123(5) 1036-1045 https://doi.org/10.1037/a0016870 PMID: 19824769

21. Jafri NF, Clarke JL, and Weinberg V, et al (2013) Relationship of glioblastoma multiforme to the subventricular zone is associated with survival Neuro-oncology 15(1) 91-96 https://doi.org/10.1093/neuonc/nos268 PMCID: 3534420

22. Chen L, Guerrero-Cazares H, and Ye X, et al (2013) Increased subventricular zone radiation dose correlates with survival in glioblastoma patients after gross total resection Int J Radiat Oncol Biol Phys 86(4) 616-622 https://doi.org/10.1016/j.ijrobp.2013.02.014 PMID: 23540348 PMCID: 3996451 
23. Lee $P$, Eppinga W, and Lagerwaard F, et al (2013) Evaluation of high ipsilateral subventricular zone radiation therapy dose in glioblastoma: a pooled analysis Int J Radiat Oncol Biol Phys 86(4) 609-615 https://doi.org/10.1016/j.jirobp.2013.01.009 PMID: 23462418

24. Gupta T, Nair V, and Paul SN, et al (2012) Can irradiation of potential cancer stem-cell niche in the subventricular zone influence survival in patients with newly diagnosed glioblastoma? J Neurooncol 109(1) 195-203 https://doi.org/10.1007/s11060-012-0887-3 PMID: 22555992

25. Evers P, Lee PP, and DeMarco J, et al (2010) Irradiation of the potential cancer stem cell niches in the adult brain improves progression-free survival of patients with malignant glioma BMC Cancer 10384 https://doi.org/10.1186/1471-2407-10-384 PMID: 20663133 PMCID: 2918578

26. Barani IJ, Cuttino LW, and Benedict SH, et al (2007) Neural stem cell-preserving external-beam radiotherapy of central nervous system malignancies Int J Radiat Oncol Biol Phys 68(4) 978-985 https://doi.org/10.1016/j.ijrobp.2007.01.064 PMID: 17467925

27. Reya T, Morrison SJ, and Clarke MF, et al (2001) Stem cells, cancer, and cancer stem cells Nature 414(6859) 105-111 https://doi. org/10.1038/35102167 PMID: 11689955

28. Chaichana K, Parker S, and Olivi A, et al (2010) A proposed classification system that projects outcomes based on preoperative variables for adult patients with glioblastoma multiforme J Neurosurg 112(5) 997-1004 https://doi.org/10.3171/2009.9.JNS09805

29. Slotman BJ, Eppinga WSC, and de Haan PF, et al (2011) Is Irradiation of Potential Cancer Stem Cell Niches in the Subventricular Zones Indicated in GBM? Int J Radiat Oncol Biol Phys 81(2) S184 https://doi.org/10.1016/j.ijrobp.2011.06.328

30. Elicin O, Inac E, and Uzel EK, et al (2014) Relationship between survival and increased radiation dose to subventricular zone in glioblastoma is controversial J Neurooncol 118(2) 413-419 https://doi.org/10.1007/s11060-014-1424-3 PMID: 24668610

31. Khalifa J, Tensaouti F, and Lusque A, et al (2017) Subventricular zones: new key targets for glioblastoma treatment Radiat Oncol 12(1) 67 https://doi.org/10.1186/s13014-017-0791-2 PMID: 28424082 PMCID: 5397708

32. Iuchi T, Hatano K, and Kodama T, et al (2014) Phase 2 trial of hypofractionated high-dose intensity modulated radiation therapy with concurrent and adjuvant temozolomide for newly diagnosed glioblastoma Int J Radiat Oncol Biol Phys 88(4) 793-800 https://doi. org/10.1016/j.jjrobp.2013.12.011 PMID: 24495592

33. Malik M, Akram KS, and Joseph D, et al Prospective study of irradiation of potential stem cell niches in glioblastoma Int J Radiat Oncol Biol Phys 93(3) S111

34. Tonse R, Sood S, and Gupta T, et al (2017) P09.61 Detailed analysis and correlation of survival with subventricular zone dosimetry in patients diagnosed with glioblastoma treated with focal conformal radiotherapy: results of a prospective trial Neuro-oncology 19(suppl_3) iii84 https://doi.org/10.1093/neuonc/nox036.316 PMCID: 5463961

35. Johannesen TB, Lien HH, and Hole $\mathrm{KH}$, et al (2003) Radiological and clinical assessment of long-term brain tumour survivors after radiotherapy Radiother Oncol 69(2) 169-176 https://doi.org/10.1016/S0167-8140(03)00192-0 PMID: 14643954

36. Silber JH, Radcliffe J, and Peckham V, et al (1992) Whole-brain irradiation and decline in intelligence: the influence of dose and age on IQ score J Clin Oncol 10(9) 1390-1396 https://doi.org/10.1200/JCO.1992.10.9.1390 PMID: 1517781

37. Ris MD, Packer R, and Goldwein J, et al (2001) Intellectual outcome after reduced-dose radiation therapy plus adjuvant chemotherapy for medulloblastoma: a Children's Cancer Group study J Clin Oncol 19(15) 3470-3476 https://doi.org/10.1200/JCO.2001.19.15.3470 PMID: 11481352

38. Hoppe-Hirsch E, Brunet L, and Laroussinie F, et al (1995) Intellectual outcome in children with malignant tumors of the posterior fossa: influence of the field of irradiation and quality of surgery Childs Nerv Syst 11(6) 340-345 discussion 5-6 https://doi.org/10.1007/ BF00301666 PMID: 7671269 
39. Schatz J, Kramer JH, and Ablin A, et al (2000) Processing speed, working memory, and IQ: a developmental model of cognitive deficits following cranial radiation therapy Neuropsychology 14(2) 189-200 https://doi.org/10.1037/0894-4105.14.2.189 PMID: 10791859

40. Penitzka S, Steinvorth S, and Sehlleier S, et al (2002) [Assessment of cognitive function after preventive and therapeutic whole brain irradiation using neuropsychological testing] Strahlenther Onkol 178(5) 252-258 https://doi.org/10.1007/s00066-002-0878-y PMID: 12082684

41. Redmond KJ, Mahone EM, and Horska A (2013) Association between radiation dose to neuronal progenitor cell niches and temporal lobes and performance on neuropsychological testing in children: a prospective study Neuro-oncology 15(11) 1455 https://doi. org/10.1093/neuonc/not213 PMID: 24174569 PMCID: 3813425

42. Khatua S, Dhall G, and O'Neil S, et al (2010) Treatment of primary CNS germinomatous germ cell tumors with chemotherapy prior to reduced dose whole ventricular and local boost irradiation Pediatr Blood Cancer 55(1) 42-46 PMID: 20222020

43. Mabbott DJ, Monsalves E, and Spiegler BJ, et al (2011) Longitudinal evaluation of neurocognitive function after treatment for central nervous system germ cell tumors in childhood Cancer 117(23) 5402-5411. https://doi.org/10.1002/cncr.26127 PMID: 21563173 